\title{
Development of a Framework for Emergency Risk Reduction in Android-Based Agriculture Areas (E'nurse App During the Covid-19 Pandemic)
}

\author{
Musviro $^{{ }^{*}}$, Suhari ${ }^{2}$, Primasari Mahardhika Rahmawati ${ }^{3}$, Anggia Astuti $^{4}$ \\ ${ }^{1 *}$ Lecturer for Diploma Degree of Nursing Faculty of Nursing, University of Jember, Indonesia; \\ musviro@unej.ac.id (Corresponding Author) \\ 2Lecturer for Diploma Degree of Nursing Faculty of Nursing, University of Jember. Indonesia \\ 3 Lecturer for Diploma Degree of Nursing Faculty of Nursing, University of Jember, Indonesia \\ ${ }^{4}$ Lecturer for Diploma Degree of Nursing Faculty of Nursing, University of Jember, Indonesia
}

\begin{tabular}{|c|c|}
\hline Article Info: & ABSTRACT \\
\hline Submitted: & Introduction: Covid-19 has now been declared a pandemic case, the agricultural sector \\
\hline 06-04-2021 & is no exception. Farmers' health during the Covid-19 pandemic and the high risk of \\
\hline Revised: & emergencies and disasters in agricultural areas need solutions in handling efforts. \\
\hline 03-06-2021 & Purpose: developing a framework for reducing the risk of emergencies and disasters in \\
\hline Accepted: & agricultural areas based on android (E'Nurse App during the Covid-19 pandemic) by \\
\hline 04-06-2021 & compiling the design of the E'Nurse App and analyzing the effect of the E'Nurse App on \\
\hline & $\begin{array}{l}\text { farmers' understanding in reducing the risk of emergencies and disasters in areas } \\
\text { agriculture. Method: a mix of qualitative methods with an interpretive phenomenology }\end{array}$ \\
\hline & approach to design the E'Nurse App (Emergency Nursing) application, followed by \\
\hline DOI: & quantitative methods with the Spearman Rho test and a questionnaire measuring tool. \\
\hline https:/ & $\begin{array}{l}\text { Respondents in this study were farmers of Pandalungan. Result: Formed the design of } \\
\text { the E'Nurse App application, the pre-post treatment test obtained the value of } r=0.678\end{array}$ \\
\hline & $\begin{array}{l}>a=0.05 . \text { This means that there is an effect of providing education through the smart } \\
\text { app application on farmers' understanding in reducing the risk of emergencies and }\end{array}$ \\
\hline & agricultural areas with a strong relationship. Conclusion: The E'Nurse App \\
\hline (c) & agricultural areas during the Covid-19 pandemic. \\
\hline
\end{tabular}

This work is licensed under CC BY-SA License.
Keywords: Risk reduction, Emergency, Disaster, Agriculture, Covid-19

\section{INTRODUCTION}

The Covid-19 virus has now become a pandemic that has spread almost all over the world. Covid-19 is a disease caused by a new type of corona virus that was first discovered in the city of Wuhan, China. The main symptoms of being infected with the Covid-19 virus are cough, fever, and shortness of breath. Covid-19 infection can cause quite high mortality in various countries, one of which is Indonesia at this time. The covid-19 virus began to spread in Indonesia in February 2020 until now as of December 2020 the patient confirmed positive for 592,900 people, was declared cured, reaching 487,445 people and while the death toll was 181.71 people, this number can increase from day to day (WHO , 2020). The government has made major countermeasures to suppress the increase in the increase in the positive number of Covid-19, one of which is starting to impose health protocols such as Large-Scale Social Restrictions (PSBB) in big cities in Indonesia. The government also requires people to carry out self-protection which is called $3 \mathrm{M}$, namely wearing masks, maintaining distance, and washing hands (Tanjungsari, 2020).

The Covid-19 pandemic currently occurring can hamper community activities, including farmers. Along with farmer activities outside the home that require farmers to continue working in the fields amid the Covid-19 pandemic, this is one of the risks of exposure to Covid-19. Farmers' knowledge of Covid-19, underestimating the use of masks, needs a solution. In addition, from the results of research by Suhari, et al (2018), stated that the ability of integrated emergency management based on agriculture nursing is still low. This also needs mutual attention and solutions during the Covid-19 pandemic.

In the age of advanced technology, farmers can equip themselves to get knowledge easily. Farmers can take advantage of the development of digital android technology to get the latest information about education and learning emergency aid in agriculture. This can allow applications to improve the quality of health of farmers which are packaged with Android technology to be accessed by farmers for health information. Response to emergencies and disasters, in 
the industrial era 4.0 and this pandemic era, researchers developed a framework for reducing the risk of emergencies and disasters in the android-based agricultural area (E'Nurse App). Purpose: developing a framework for reducing the risk of emergencies and disasters in agricultural areas based on android (E'Nurse App during the Covid-19 pandemic) by compiling the design of the E'Nurse App and analyzing the effect of the E'Nurse App on farmers' understanding in reducing the risk of emergencies and disasters in areas agriculture.

\section{METHOD}

Research design Mix method qualitative approach to interpretative phenomenology followed by quantitative. Interpretive phenomenology to explore farmer problems in the Covid-19 era with farmer participants through FGD (Focus Group Discussion) and literature reviews. The results of the FGD were made by designing the E'Nurse App (Emergensy Nursing) application, measuring the pre-post E'Nurse App using a questionnaire and tested with Spearman Rho. This research was conducted in Lumajang from October to December.

The study was conducted on 30 respondents who work as farmers, including the availability of technological facilities and infrastructure in the neighborhood where the respondent lives. Sampling was carried out through representation from all existing farmer groups. Every farmer has an android based cell phone.

The instrument used in developing a framework for reducing the risk of emergencies and disasters in agricultural areas uses an interview sheet. Pre Post E'Nurse App uses a questionnaire, multiple choise type. The questions consist of general data and 10 questions about farmers' understanding of covid-19 and its prevention as wellisk reduction of emergencies and disasters in agricultural areas. Data analysis was carried out by descriptive and quantitative analysis. The data obtained is processed first and scoring is carried out to analyze the levelunderstanding of farmers in reducing the risk of emergencies and disasters in agricultural areas pre and post E'Nurse App.

This research was submitted to the Research Ethics Commission of the Faculty of Dentistry, University of Jember with No.1053 / UN25.8 / KEPK / DL / 2020. Besides being carried out at home, this activity was carried out by a meeting of several farmers by implementing the covid-19 prevention health protocol. In introducing the application, accompanied by the instructor who is in the neighborhood where the respondent lives around him, in implementing the results of the introduction of this Android-based application it can help inreduction of the risk of emergencies in agricultural areas during the Covid-19 epidemic.

\section{RESULT}

\section{Characteristics of Respondents}

The following is distribution of respondent characteristics:

Table 1. Characteristics of Respondents

\begin{tabular}{lcc}
\hline \multicolumn{1}{c}{ Characteristics } & Frequency & Percentage \\
\hline Age & 0 & \\
12-18 years & 21 & $0 \%$ \\
19-50 years & 8 & $70 \%$ \\
51-65 years & 1 & $27 \%$ \\
65 years and over & 25 & $3 \%$ \\
\hline Gender & 5 & $83 \%$ \\
$\quad$ Man & & $17 \%$ \\
$\quad$ Women & 4 & \\
\hline Last education & 6 & $13 \%$ \\
$\quad$ No school & 6 & $20 \%$ \\
SD & 10 & $20 \%$ \\
Junior High & 4 & $33 \%$ \\
High school & & $13 \%$ \\
$\quad$ Diploma / Bachelor Degree & 7 & \\
\hline Length of work & 6 & $23 \%$ \\
Less than 5 years & 17 & $20 \%$ \\
5-10 Years & & $57 \%$ \\
More than 10 Years & &
\end{tabular}


Table 1 shows that most of the respondents were aged 19-50 years, with the sex of most of them male, and almost half of them had graduated from high school with a long time working as farmers, mostly more than 10 years.

\section{The Effect of E'Nurse App on Farmers' Understanding in Reducing the Risk of Emergencies and Disasters in Agricultural Areas}

The following is a table of the effect of the E'Nurse App on farmers' understanding in reducing the risk of emergencies and disasters in agricultural areas.

Table 2. The Effect of E'Nurse App on Farmers' Understanding in Reducing the Risk of Emergencies and Disasters in Agricultural Areas

\begin{tabular}{lcccc} 
& & Pre knowledge & Knowledge Post \\
\hline \multirow{2}{*}{ Spearman's rho } & Pre knowledge & Correlation Coefficient & 1,000 & .079 \\
& & Sig. (2-tailed) &. & .678 \\
& N & 30 & 30 \\
& Knowledge Post & Correlation Coefficient & .079 & 1,000 \\
& & Sig. (2-tailed) & .678 &. \\
& & $\mathrm{~N}$ & 30 & 30
\end{tabular}

Table 2 shows that there is an influence between pre and post E'Nurse App as evidenced by the value of $r=$ $0.678>a=0.05$ and a strong relationship.

\section{DISCUSSION}

\section{Characteristics of Respondents}

The results of this study indicate that Most of the respondents were 19-50 years old, with the sex of most of them male, and almost half of them had high school education with the length of time working as farmers were mostly more than 10 years.Characteristics of respondents are considered as one of the most important elements in determining the characteristics of the effectiveness of the research, these characteristics are explained by changes in age, gender, education and length of work.(Wibowo \& Haryanto, 2020). The development of a person's age is followed by intelligence. This age development can affect a person in thinking and working. The age factor can affect the performance performed by a farmer and can also affect one's performance (Thamrin, 2017). The level of education taken by individuals can affect the level of thinking and reasoning in making decisions (Ardelia, et al., 2020). According to (Thamrin, 2017), education will shape and increase farmers' knowledge, the higher a person's education level, the broader his / her insight into a problem will be, so that they can think better about how a job can be completed faster, better. and appropriate.

Differences in the value of knowledge between respondents can be caused by various factors, such as education and age. The difference in the level of knowledge of a person can be seen through the level of education, the higher the education, the easier it is to accept new things and the easier it is to be absorbed. This is in accordance with the opinion(Hamdalah, et al., 2020), states that the factors of education, age, occupation and information can affect a person's knowledge.In the group of farmers who have worked as farmers for more than 10 years, the long experience working as a farmer is one of the indirect means of increasing the livelihood of the farmers, the longer the farmers are in farming, it is hoped that the farmers will be able to manage their farming properly. So that it is hoped that the resulting production will increase. This situation proves that farmers work as farmers for more than 10 years on average. The longer farming experience, the farmers will have broader skills and knowledge about farming. Older farmers have more mature farm management capacities and more experience than younger farmers (Sarni \& Sidayat, 2020).

There are many differences in the level of knowledge of farmers in accessing information sources, including differences in the roles of responsibilities, age and gender (Ardelia, et al., 2020). This is in accordance with the theory that the characteristics of the respondent are one of the elements in receiving and understanding the information received. 


\section{The Effect of Using the E'Nurse App on the Understanding of Inner Farmers Emergency Risk Reduction in Agricultural Areas}

The results showed that there was an effect of using the E'Nurse App on farmers' understanding of reducing the risk of emergencies in agricultural areas and the relationship was strong. Farmers' knowledge is influenced by several factors including ease of access to information, speed in obtaining information, and awareness / understanding of the benefits of using information technology. A person's understanding can be influenced by the media used. The use of moving image and audio elements in video media can make it easier for respondents to understand or capture information. The use of live or moving images to convey information will give higher test results compared to mapping, modelling and drawing alone (Nurdin, et al., 2020). Strengthened in opinion (Nurdayati, et al., 2020), states that an attractive and clear projected image or video will generate attention and the content can be viewed repeatedly and makes it easier for someone to receive information.

This study uses the E'Nurse App design application media and various video media containing the E'Nurse App application and the benefits of using image elements. An understanding of the application using videos. The ease of accessing information can increase farmers' motivation in seeking information. Respondents stated that the design of the E'Nurse App application is quite easy to access and has a simple and concise appearance so that it can be used. Farmers are part of the users who should be able to adopt media-based technological developments (Kusumadinata, 2016). The existence of agricultural applications can be a medium for delivering material and information to make it easier for farmers. These various conveniences are expected to be able to change farmers closer to the digital world and no longer be technologically illiterate (Prayoga, 2015). This can form digital farmers who are able to use the internet for various purposes. Community participation will also be active in agricultural activities.

The use of the E'Nurse App is able to accelerate farmers in obtaining information. This is evidenced by the majority of respondents agree with this statement. In addition, in today's era, information delivery is much more carried out in virtual spaces. Most farmers have used an android / smartphone to access the desired information (Prayoga, 2015), so that problems such as a lack of knowledge regarding the dangers of covid-19 and handling of snake bites can be overcome with the existence of the E'Nurse App. Information technology-based media development is one of the alternatives to ensure the speed and accuracy of the dissemination of information on new technologies in agriculture (Subejo, 2011).

Increased knowledge of farmers in reducing emergency risks in agricultural areas is also related to the level of awareness / understanding of the benefits of using information technology. In this case, almost all respondents understand the benefits of using digital as a medium of information. The higher the percentage of access infrastructure, the higher the availability of existing information technology-based information facilities will encourage the higher level of farmer behavior in increasing innovativeness and awareness of finding the information needed (Ardelia, et al., 2020). Information technology has been included in agricultural development. This can increase awareness among young and middle-aged farmers about the availability of information technology-based information in order to increase their participation and initiative (Usman et.al, 2012).

The development of technology and information in the agricultural era, especially in the era of the Covid-19 pandemic, is currently considered significant and important for farmers. Through various activities and involving several people in accessing information technology, it is hoped that farmers will demonstrate an increase in knowledge so that it can be donereduction of the risk of emergencies in the Android-based agricultural area during the Covid-19 pandemic. Support for technology access facilities is an element of infrastructure in fulfilling farmers' access to technology, both through the physical and social environment (Ardelia, et al., 2020).

\section{CONCLUSION}

There is an effect of the E'Nurse App on farmer's understanding in reducing the risk of emergencies and disasters in agricultural areas, especially in Covid-19 pandemic. There is a significant effect of the E'Nurse App on farmers.

\section{ACKNOWLEDGEMENT}

The researcher would like to thank the University of Jember, the Lumajang District Health Office, the Lumajang Regency Agriculture Office and the respondents. 


\section{REFERENCES}

Anwas, O. M. (2009). Pemanfaatan Media dalam Pengembangan Kompetensi Penyuluh Pertanian. Disertasi : Program Studi Ilmu Penyuluhan Pembangunan Departemen Sains Komunikasi dan Pengembangan Masyarakat Pasca Sarjana IPB Bogor.

Ardelia, R., Anwarudin, O. \& Nazaruddin. (2020). Akses Teknologi Informasi Melalui Media Elektronik Pada Petani KRPL. Jurnal Triton, 11(1), 24-36.

Ernah \& Wulandari, E. (2020). Peningkatan Pengetahuan Petani Melalui Sosialisasi Daring Tech For Farmers. JURNAL ABDIDAS, $1(6), 838-841$.

Hamdalah, Satmoko \& Gayatri. (2020). Tingkat Pengetahuan Petani T Erhadap Aplikasi Sipindo Di Kelompok Tani Vanda Subur Kelurahan Cepoko Gunung Pati Kota Semarang. Agromedia, 2 September, 38(2), 51-59.

Kusumadinata. (2016). Penggunaan Internet Di Kalangan Petani Sayur Dalam Memperoleh Informasi Pertanian Di Kabupaten Cianjur. Indonesian Journal Of Agricultural Economics (IJAE) .

Kemenkes RI. (2020) 'Pedoman Pencegahan Dan Pengendalian Coronavirus Disease (COVID-19)', Germas.

Mamilianti, W. (2020). Persepsi Petani Terhadap Teknologi Informasi Dan Pengaruhnya Terhadap Perilaku Petani Pada Risiko Harga Kentang. Jurnal IImu-IImu Pertanian, 14(2), 125-139.

Muhammad Thamrin, S. H. D. F. H. (2017). Pengaruh Faktor Sosial Ekonomi Terhadap Pendapatan Petani Pinang. Agrium, 17(2), 85-94.

Nurdayati, Putra, R. D. \& Pramu. (2020). Hubungan Keterdedahan Terhadap Media Informasi Dengan Tingkat Pengetahuan Petani Tentang Pencegahan Penyakit Cacing Pada Ternak Sapi. Jurnal Penelitian Peternakan Terpadu, 2(2), 70-78.

Nurdin, Jamin, F. S., Taha, S. R. \& Moonti, A., 2020. Peningkatan Pengetahuan Dan Ketrampilan Petani Dalam Pembuatan Pakan Silase Di Kelompok Tani Rukun Sejahtera Desa Bualo Kabupaten Boalemo. Jurnal Abdi Insani Universitas Mataram, 7(2), 225-234.

Prayoga, K. (2015). Aplikasi Digital Pertanian: Geliat Pemberdayaan Petani Era Virtual. Universitas Gajah Mada , 1-7.

Simarmata. (2019). Percepatan Transformasi Teknologi Dan Inovasi Dalam Era Smart Farming Dan Petani Milenial Untuk Meningkatkan Produktivitas , Nilai Tambah Dan Daya Saing Pertanian Indonesia. Kuliah Umum Universitas Mataram .

Subejo. (2011). Babak Baru Penyuluhan Pertanian dan Pedesaan. Jurnal IImu Pertanian, 7(1), 61-70.

Sarni \& Sidayat, M., (2020). Dampak Pandemi Covid 19 Terhadap Pendapatan Petani Sayuran Di Kota Ternate. Prosiding Seminar Nasional Agribisnis, 2(1), 144-148.

Usman, Adeboye, Oluyole, \& Ajijola. (2012). Use Information and Communication Technologies bt Rural Farmers in Oluyole Local Goverment Area Of Oyo State, Nigeria. Journal of Stored Product and Postharvest Research, 3(11), 156-159.

Tanjungsari, A., (2020). Strategi Pemberdayaan Peternak Sapi Bali Akibat Pandemi Covid-19 Di Desa Tiga, Kecamatan Susut, Kabupaten Bangli, Provinsi Bali. Jurnal Biologi Dan Pembelajarannya, 7(2), 8-14.

Wibowo, H. T. \& Haryanto, Y., (2020). Kinerja Penyuluh Pertanian Dalam Masa Pandemi Covid-19 Di Kabupaten Magelang. Jurnal Penelitian Peternakan Terpadu, 2(2), 79-92. 